\title{
Biofloc technology: an emerging avenue in aquatic animal healthcare and nutrition
}

\author{
$\operatorname{Irshad~Ahmad}^{1}$ - A. M. Babitha Rani ${ }^{1}$ - A. K. Verma ${ }^{1}$ • \\ Mudasir Maqsood ${ }^{2}$
}

Received: 9 May 2016 / Accepted: 22 December 2016 / Published online: 11 January 2017

(C) The Author(s) 2017. This article is published with open access at Springerlink.com

\begin{abstract}
Biofloc is a conglomeric aggregation of microbial communities such as phytoplankton, bacteria, and living and dead particulate organic matter. Biofloc technology involves manipulation of $\mathrm{C} / \mathrm{N}$ ratio to convert toxic nitrogenous wastes into the useful microbial protein and helps in improving water quality under a zero water exchange system. It may act as a complete source of nutrition for aquatic organisms, along with some bioactive compounds that will enhance growth, survival, and defense mechanisms, and acts as a novel approach for health management in aquaculture by stimulating innate immune system of animals. Nutritionally, the floc biomass provides a complete source of nutrition as well as various bioactive compounds that are useful for improving the overall welfare indicators of aquatic organisms. Beneficial microbial bacterial floc and its derivative compounds such as organic acids, polyhydroxy acetate and polyhydroxy butyrate, could resist the growth of other pathogens, thus serves as a natural probiotic and immunostimulant. The technology is useful in maintaining optimum water quality parameters under a zero water exchange system, thus prevents eutrophication and effluent discharge into the surrounding environment. Moreover, the technology will be useful to ensure biosecurity, as there is no water exchange except sludge removal. The technology is economically viable, environmentally sustainable, and socially acceptable.
\end{abstract}

Keywords Bioflocs $\cdot \mathrm{C} / \mathrm{N}$ ratio $\cdot$ Immunostimulation - Nutritional composition $\cdot$ Carbon sources Biosecurity $\cdot$ Zero water exchange systems $\cdot$ Sustainability

Irshad Ahmad

irshad.ahmad620@gmail.com

1 ICAR-Central Institute of Fisheries Education, Panch Marg, Yari Road, Versova, Andheri (W), Mumbai 400061, India

2 Sher-e-Kashmir University of Agricultural Sciences and Technology (Kashmir), Srinagar, Jammu \& Kashmir 190006, India 


\section{Introduction}

To support the rapidly growing human population, food production industries such as aquaculture also needs horizontal as well as vertical expansion. The rapid growth of global aquaculture industry cannot be over emphasized because environmental and economical limitations can hamper this growth. Intensification of the aquaculture activities generates an immense amount of excess organic pollutants that are likely to cause acute toxic effects and long-run environmental risks (Piedrahita 2003). The foremost common method of dealing with this problem has been the utilization of continuous replacement of the pond water through the exchange (Gutierrez-Wing and Malone 2006). The water volume required for even small to medium culture systems can reach up to several hundreds of cubic meters per day. Parenthetically $20 \mathrm{~m}^{3}$ of water is required for the production of $1 \mathrm{~kg}$ shrimp (Wang 2003). A recirculating aquaculture system (RAS) is another approach for the removal of major toxic pollutants from the culture water without causing environmental concerns (Gutierrez-Wing and Malone 2006). The beneficial effect of this technology is that only $10 \%$ of the total water volume is needed to be replaced on a daily basis (Twarowska et al. 1997), but due to the high operational and maintenance cost, the adoption of RAS among the farming community especially in developing countries is low. Therefore, there was a wide search for years for a low cost, sustainable, and environment-friendly technology for large-scale adoption. Biofloc technology has gained attentions recently as a sustainable and eco-friendly method of aquaculture which controls water quality, along with the production of value added microbial proteinaceous feed for the aquatic organisms. The use of BFT systems in the marine shrimp aquaculture has been extensively studied (Emerenciano et al. 2011, 2012b, 2013b; Ray et al. 2011; Xu and Pan 2012; da Silva et al. 2013; Schveitzer et al. 2013; de Souza et al. 2014; Kumar et al. 2014). The technology is cost-effective and environment-friendly and supports sustainable aquaculture (Naylor et al. 2000; Avnimelech and Kochba 2009). The different aspects of such a system can be summarized under the following headings.

I. Biofloc technology

II. Carbon-nitrogen ratio

III. Microbial community in bioflocs

IV. Nutritional composition of bioflocs

V. Biofloc as a dietary stimulant

VI. Immuno-physiological response by bioflocs

VII. Bioflocs in aquaculture

\section{Biofloc technology}

Biofloc technology (BFT) is based on the maintenance of high levels of microbial bacterial floc in suspension using constant aeration and addition of carbohydrates to allow aerobic decomposition of the organic material (Avnimelech and Weber 1986). By adding carbohydrates, heterotrophic bacterial growth is stimulated and production of microbial proteins takes place through nitrogen uptake (Avnimelech 1999). Maintaining the $\mathrm{C} / \mathrm{N}$ ratio in the aquaculture system, through the external addition of carbon source or elevated carbon level in the feed, water quality can be improved along with the production of high-quality single-cell microbial protein (Crab et al. 2012). Under such conditions, dense microorganisms develop, functioning 
both as bioreactor controlling water quality (Avnimelech et al. 1989) and also acts as protein food source for the fishes and shrimps (Avnimelech et al. 1994). Immobilization of toxic nitrogen species occurs much more rapidly in bioflocs because the growth rate and microbial biomass production per unit substrate of heterotrophs are 10 times higher than those of autotrophic nitrifying bacteria (Hargreaves 2006). The technology works on the basic principle of flocculation (co-culture of heterotrophic bacteria and algae) within the system (Avnimelech 2006). Biofloc technology (BFT) has been successfully implemented in aquaculture especially shrimp farming due to economical, environmental, and marketing advantages over a conventional culture system. Compared to conventional aquaculture techniques, biofloc technology provides more economical alternative and sustainable technique in terms of minimal water exchange and reduced feed input making it a low-cost sustainable technology for sustainable future aquaculture development (Avnimelech and Kochba 2009; De Schryver et al. 2008). As a startup for biofloc technology, it might be interesting to investigate the effect of adding nucleation sites to the lined ponds which include adding calculated amounts of pond bottom clay to the water at startup to stimulate floc formation. In addition, the inoculation with water from existing biofloc ponds or a prepared inoculum (20 g of pond bottom soil, $10 \mathrm{mg}$ ammonium sulfate $(\mathrm{NH})_{4} \mathrm{SO}_{4}$ and $200 \mathrm{mg}$ of carbon sources in 11 of water) might allow an accelerated startup. McAbee et al. (2003) and Gaona et al. (2011) suggested the use of nucleation sites such as soil or biofloc-rich water as inoculum from a prior production cycle accelerates the formation of microbial flocs in the new culture system. Compared to the productivity of various eco-friendly farming practices, the intensive farming methods with limited water exchange provide a sustainable alternative for farming intensification and biosecurity.

\section{Carbon-nitrogen ratio}

Carbon-nitrogen ratio $(\mathrm{C} / \mathrm{N})$ in the aquatic environment plays an important role in the immobilization of toxic inorganic nitrogen compounds into useful bacterial cells (single-cell protein) that may act as a direct source of food for the cultured organisms (Avnimelech 1999). Immobilization of inorganic nitrogen takes place when the $\mathrm{C} / \mathrm{N}$ ratio of the organic matter is higher than 10 (Lancelot and Billen 1985). Thus, alteration in the $\mathrm{C} / \mathrm{N}$ ratio may result in a shift from an autotrophic to a heterotrophic system (Avnimelech 1999; Browdy and Bratvold 2001). Once a mature biofloc community is established, TAN and $\mathrm{NO}_{2}-\mathrm{N}$ concentrations can be effectively controlled by either heterotrophic assimilation or autotrophic nitrification that helps to maintain their concentrations at acceptable ranges for the cultured organisms even at higher stocking densities (Xu et al. 2016). By adding a carbon source (direct or indirect $\mathrm{C}$ sources) to the culture medium in limited-discharge systems (changing $\mathrm{C} / \mathrm{N}$ ratio), it is possible to obtain a significant enhancement of useful microbial growth and the fixation of toxic nitrogen metabolites (Ebeling et al. 2006; Hari et al. 2006; Avnimelech and Kochba 2009; Crab et al. 2010). As the $\mathrm{C} / \mathrm{N}$ ratio of bacterial cells is 5:1 (Rittmann and McCarty 2001) and the conversion efficiency of bacteria is $40-60 \%, \mathrm{C} / \mathrm{N}$ ratio of 10 or more in the feed is required for the growth of heterotrophic microorganisms (Avnimelech 1999). The bacterial process transforms the toxic form of nitrogen (ammonia and nitrite) to one that is toxic only at high concentrations (nitrate) by the process called nitrification. The BFT being zero water exchange system thus tends to accumulate the nitrate in the long run, and hence usually the nitrate level in biofloc systems increases as the culture progresses. Kuhn et al. (2009) observed that carbon 
supplementation enhanced the removal rates of TAN at $26 \%$ per hour compared to $1 \%$ per hour in a control system. The $\mathrm{C} / \mathrm{N}$ ratio of around 10 is maintained in most of the feeds used in semi-intensive aquaculture ponds, but bacteria require about 20 units of carbon per unit of nitrogen assimilated (Avnimelech 1999). So, when $\mathrm{C} / \mathrm{N}$ ratio is low in the feed, carbon becomes the limiting nutrient for the growth of heterotrophic bacterial populations in the aquaculture ponds (Asaduzzaman et al. 2009) and hence the heterotrophic bacterial population will not inflate beyond a certain point due to the limited availability of carbon in the system. The $\mathrm{C} / \mathrm{N}$ ratio in an aquaculture system can be increased by adding different locally available cheap carbon sources (agricultural by-products) and also by the reduction of protein content in the feed (Avnimelech 1999; Hargreaves 2006). Different organic carbon sources (glucose, cassava, molasses, wheat, corn, sugar bagasse, sorghum meal, etc.) are used to enhance production and to improve the nutrient dynamics through altered $\mathrm{C} / \mathrm{N}$ ratio in shrimp culture (Avnimelech 1999), and C/N ratio is also widely used as a guide for analyzing the decomposition of organic matter (Alexander and Ingram 1992). The reduction of toxic nitrogenous compounds from the intensive, well-aerated systems can be achieved by the application of organic carbon sources and by altering the $\mathrm{C} / \mathrm{N}$ ratio in the feed (Avnimelech 1999; Browdy and Bratvold 2001). The biofloc system maintained with $\mathrm{C} / \mathrm{N}$ ratio of higher than 15-20 will be developing sufficient microbial floc to assimilate toxic nitrogenous species under intensive farming with limited discharge. Recently, a lot of work has been published in biofloc technology regarding the manipulation of $\mathrm{C} / \mathrm{N}$ ratio, and also Biofloc Technology: A Practical Guide Book that is directed to farmers and researchers is a tremendous step forward in providing information on this technology (Avnimelech 2015).

\section{Microbial community in bioflocs}

Two functional categories of bacterial populations are primarily responsible for water quality maintenance in minimal or zero water exchange systems (intensive systems) viz., heterotrophic ammonia-assimilative and chemoautotrophic nitrifying bacteria (Ebeling et al. 2006; Hargreaves 2006). The color changes from green to brown which takes place as the culture progresses due to the transition from a mostly algal-dominant to a bacterial biofloc-dominant system. The number of bacteria in biofloc ponds can be between $10^{6}$ and $10^{9} / \mathrm{ml}$ of floc plug which contains between 10 and $30 \mathrm{mg}$ dry matter making the pond a biotechnological industry (Avnimelech 2007). Microbial communities formed consist of phytoplankton, bacteria, and aggregates of living and dead particulate organic matter (Hargreaves 2006). According to Ju et al. (2008), bioflocs collected from Litopenaeus vannamei tanks contained $24.6 \%$ phytoplankton (dominated by diatoms like Thalassiosira, Chaetoceros, and Navicula), $3 \%$ bacterial biomass (two thirds was gram-negative and one third gram-positive ), a small amount of protozoan community ( $98 \%$ flagellates, $1.5 \%$ rotifers, and $0.5 \%$ amoeba), and $33.2 \%$ detritus, and the remaining quantity was ash (39.25\%). Only 2-20\% of the organic fraction of sludge flocs is believed to be living (microbial cells) while the rest is of total organic matter (60-70\%) and total inorganic matter (30-40\%) (Wilen et al. 2003). Dominant bacterial species that are present in the bioflocs include Proteobacterium, Bacillus species, and Actinobacterium. Besides this, there are some other minor bacterial species such as Roseobacter sp. and cytophaga sp. (Zhao et al. 2012). In conventional activated sludge systems, efficient aggregation is of principal importance, since their operational success depends heavily on good settling sludge (Bossier and Verstraete 1996). The heterotrophic bacterial population utilizes the 
ammonium in addition to the organic nitrogenous wastes to synthesize single-cell microbial protein (Schneider et al. 2006) which act as natural feed for shrimps (Burford et al. 2004). The sinking rate of floc aggregate will be slow at a velocity of 1 to $3 \mathrm{~m} / \mathrm{h}$ when densities of the microbial biomass move slightly above $1 \mathrm{~g}$ wet weight $/ \mathrm{ml}$ (Sears et al. 2006). As the bacteria move through the water column, efficient laminar regime (Reynolds envelope) which is always present around bacteria which are smaller than $100 \mu \mathrm{m}$ interferes with the nutrient mass transfer. When the rate of substrate consumption exceeds the rate of substrate supply, mass transfer limitations take place (Simoni et al. 2001).

\section{Nutritional composition of bioflocs}

Nutritionally, the floc biomass could provide a complete source of nutrition as well as various bioactive compounds (Akiyama et al. 1992). The nutritional value of bioflocs is dependent on several factors such as food preferences by the animal, their ability to ingest and digest microbial protein, and the floc density in the water (Hargreaves 2006). The single-cell protein formed by heterotrophic bacterial population through uptake of inorganic $\mathrm{N}$ can be utilized as a source of food for cultured animals like shrimps, tilapia, and carps (Rahmatullah and Beveridge 1993; Burford et al. 2004; Mahanand et al. 2013). In terms of quality, biofloc contains $38 \%$ protein, $3 \%$ lipid, $6 \%$ fiber, $12 \%$ ash, and $19 \mathrm{~kJ} / \mathrm{g}$ energy (on dry matter basis) (Azim and Little 2008). Azim and Little 2008 observed 50\% crude protein, 2.5\% crude lipid, $4 \%$ fiber, $7 \%$ ash, and $22 \mathrm{~kJ} \mathrm{~g}^{-1}$ energy and reported that the quality of biofloc is independent of the quality of feed used for biofloc production (35 and 22\% crude protein). Ballester et al. (2010) reported that bioflocs contain $30.4 \%$ crude protein, $4.7 \%$ crude lipid, $8.3 \%$ fiber, $39.2 \%$ ash, and $29.1 \%$ nitrogen free extract on dry matter basis when wheat bran and molasses were used as carbohydrates sources. Thus the change in the carbon source changes the nutritional composition and quality index of the flocs. Besides these characteristics, the type of carbon source also influences the palatability and digestibility of the cultured organisms (Crab 2010a; Crab et al. 2009). Overall, bioflocs produced on glycerol gave the best results (Crab 2010a). Biofloc enhances ingestion rate, nutrient absorption, and assimilation, and provides a complete source of cellular nutrition (Tacon et al. 2002). Broodstock diets fortified with biofloc supplementation improve reproductive performance in terms of fecundity, spawning, and egg biochemical composition in Farfantepenaeus duorarum and L. Vannamei (Emerenciano et al. 2012a, 2014). Tilapia culture inactivated suspension ponds indicated that the fish grew well on low-protein feed (Avnimelech 1999; Milstein et al. 2001). Bioflocs are rich in proteins, vitamins, and minerals (Brown et al. 1997; Tacon et al. 2002). Ju et al. (2008) studied the amino acid profile of the biofloc and reported that bioflocs have a better essential amino acid index (0.92-0.93) with histidine and taurine as the most abundant amino acids. However, arginine and lysine were found to be the limiting amino acids in the biofloc (Avnimelech 1999).

Consumption and regeneration of bioflocs can increase feed utilization efficiency of the microbial population by recycling feed residues and/or recovery of some fraction of excreted nutrients (Hargreaves 2006). The microorganism not only removes excess nutrient but also improves growth rate, feed conversion ratio, and weight gain in shrimps and tilapia (Burford et al. 2004; Wasielesky et al. 2006). Although bioflocs meet nutritional standards, nutritional properties and the ability to maintain water quality in the BFT system depend on the carbon source used to produce the flocs. Different carbon sources are not only used to manipulate the 
$\mathrm{C} / \mathrm{N}$ ratio and stimulate the specific bacteria, protozoa, and algae but also to influence the microbial composition and community organization of the bioflocs (Crab et al. 2009; Crab 2010a). L. vannamei production rates and water quality were maintained without water exchange using a biofloc system supplemented with dextrose or molasses (Antonio et al. 2015). According to Avnimelech (2007) and Emerenciano et al. (2013b), the bioflocs are rich in natural protein and lipid and hence serve as natural in situ food for culture organisms while at the same times act as bio-control to the system by treating the feeding waste and reducing ammonium concentrations (Crab et al. 2007; De Schryver et al. 2008; Hargreaves 2013) thereby maintaining the water quality. However, further research should focus on the use of cheap and fermented non-conventional agro-industrial residues as carbon sources to upgrade wastes as healthy feeds and to find means of fish meal replacement for the aquatic organisms.

\section{Bioflocs as dietary stimulant}

Bioflocs or its attached microorganisms could exert a positive effect on the digestive enzyme activity of shrimp (Xu and Pan 2012). Inclusion of bioflocs in the diet at BFT 75\% results in improved growth performances and digestive enzyme activity of the common carp ( Najdegerami et al. 2016); also biofloc as a dietary supplement at a $4 \%$ level in shrimp feed can enhance the growth and digestive enzyme activities in P. monodon (Anand et al. 2014). Bioflocs have been recently projected as a possible novel strategy for disease management with the "natural probiotic effect" in contrast to conventional approaches such as antibiotic, antifungal, and external probiotic and prebiotic application (Emerenciano et al. 2013a). According to the original definition, probiotics are "organisms and substances which contribute to intestinal microbial balance". Fuller (1989) revised the definition as "live microbial feed supplement which beneficially affects the host animal by improving its intestinal microbial balance". Therefore, several terms such as "friendly", "beneficial", or "healthy" bacteria are also commonly used to describe probiotics. Presently, research is going on in the field of probiotic biofloc (bio-engineered biofloc) in which beneficial probiotic bacterial strains are added to the biofloc to increase the bio-control over the pathogenic microbes and to improve the quorum-sensing ability of beneficial bacterial population present in the floc, as probioticbased biofloc showed a bio-control effect towards the pathogenic vibrio species (Crab 2010a). Bioactive compounds present in the floc cultures were considered to be effective enhancers of growth and immunity in fishes and shrimps (Burford et al. 2004; Ju et al. 2008; Linan-Cabello et al. 2002). In biofloc-based rearing units, excess nitrogen and carbon sources will lead to the development of mixed cultures which accumulate polyhydroxy butyrate (PHB) (Salehizadeh and Van Loosdrecht 2004). When the bacterial cell death or lysis happens in the culture system, there will be degradation of PHB through the activity of extracellular PHB depolymerase enzymes which are widely found in the microbes (Jendrossek and Handrick 2002). The activity of extracellular PHB depolymerase enzymes results in the release of 3 hydroxyl butyrate into the surrounding environment (Trainer and Charles 2006). PHB can act as a prebiotic for the cultured organisms. Prebiotics also known as immunosaccharides are indigestible food ingredients that selectively and beneficially affect the host by stimulating the growth of one or a limited number of bacteria in the colon thus changing the composition of gut microflora. The carbohydrates added to the BFT can also act as a source of prebiotics to the cultured organisms and could modulate the gut microbial population which is beneficial to improve the health status of the cultured organisms. Further research should be directed to 
know the role and activity of immunostimulatory and bioactive compounds present in the biofloc, since the technology deals with bacteria and bacterial products.

\section{Immuno-physiological response by bioflocs}

The knowledge of immunology has diversified greatly due to the variety of fish that are farmed and the inclusion of species such as zebra fish to the animal model repertoire in comparative immunological studies (Van Der Sar et al. 2004; Yoder et al. 2002). The immune system of fish acts as a crossroad between innate and adaptive immune responses and is hardened to the environment and the poikilothermic nature of the fish (Tort et al. 2003). The immune responses initiated by injury or by pathogenic invasion will entail phagocytosis and inflammatory processes (Corbel 1975) assisted by non-specific immune cells such as macrophages, neutrophils, and non-specific cytotoxic cells. When bacterial load increases in the adjacent water, they stimulate the release of high molecular weight glycoproteins from fish skin mucus (van der Marel et al. 2010). A number of humoral factors are released by the fishes, once they are exposed to the pathogens, such as cytokines, anti-proteases, peroxidases, lysozymes, etc. Among them, lysozyme is a preferred marker of the immune response. Lysozyme acts as an anti-inflammatory and antiviral agent, besides its high potential for bactericidal or bacteriolytic activity against pathogenic gram-positive and gram-negative bacteria (Saurabh and Sahoo 2008). Recently, researchers have hypothesized possibilities of immunostimulatory features of the bioflocs leading to enhancement of the immunity and antioxidant status of shrimps and fishes to provide broad-based resistance towards many infections (Crab et al. 2012; Xu and Pan 2013; Ahmad et al. 2016). The heterotrophic microbial biomass is suspected to have a controlling effect on pathogenic bacteria (Michaud et al. 2006). Ju et al. (2008) reported that floc carotenoids have been shown to provide essential nutritional and many bioactive physiological functions in animal tissue, including stimulating the animal immune system. The disruption of quorum-sensing, bacterial cell-to-cell communication system is a new strategy to control bacterial infection in aquaculture. Interestingly, a similar phenomenon was observed in bioflocs grown on glycerol against Vibrio harveyi in Artemia franciscana culture (Crab et al. 2010); it was also speculated that microbial flocs contain many strains of probiotics bacteria (Bairagi et al. 2002).

Most of the existing immunostimulants available are a group of live and synthetic compounds derived from bacteria and bacterial products and also extracts from plants and animals (Wang et al. 2008). Since biofloc technology deals with the bacterial environment, it might also contain some immunostimulatory compounds that are beneficial for the health of cultured organisms. Microorganisms and their cell components have been studied and applied as probiotics or immunostimulants in order to improve the innate immunity and antioxidant status of the shrimp, thereby enhancing their disease resistance (Ninawe and Selvin 2009; Smith et al. 2003; Vazquez et al. 2009). Even though bioflocs have been confirmed as being the richest source of natural microorganisms and bioactive compounds, little effort was made to study its effect on the physiological health of cultured shrimp, particularly concerning immune and antioxidant defense systems. Jang et al. (2011) found that the expression of a prophenol oxidase-activating enzyme (lvPPAE1) in hemocytes of L. vannamei was enhanced significantly when shrimp were reared in a biofloc for a long term. More recently, BecerraDorame et al. (2014) reported that L. vannamei reared in biofloc-based systems showed improved physiological performance as indicated by selected hemolymph parameters 
including superoxide dismutase activity. Most probably, some active microorganisms enter a shrimp body continuously along with the process of ingesting biofloc (Johnson et al. 2008) and then modulate the immune system of the host whether as viable microbes or microbial components (Jang et al. 2011). Therefore, in order to improve the welfare of fishes in aquaculture, further work needs to be carried out in the exact nature of humoral innate or cellular immune response and to determine the protective biofloc life of bacteria. Finally, this paper proposes a long-term perspective of bioflocs that can be used as a strategic control of diseases in aquaculture.

\section{Bioflocs in aquaculture: future prospectus}

A number of beneficial features are associated with biofloc technology along with 10-20\% potential feed gain as estimated by application of biofloc technology (Crab et al. 2007; De Schryver et al. 2008) to nitrogen recovery from the culture system. This increase was based on the internal recirculation of nutrients through the formation of new microbial biomass, which was subsequently grazed by the fish (Avnimelech 2006). The advantages of the technology in aquaculture has been well documented which includes low feed and water input (economical), less risk of pathogen introduction and diseases, more biosecurity, increased growth and survival, and hence increased crop yield (Otoshi et al. 2009; Crab et al. 2009; Samocha et al. 1998, 2007; Krummenauer et al. 2011; Perez-Fuentes et al. 2013). It also lowered the feed conversion rate by utilizing the in situ natural feed and has small footprints, hence reducing environmental impacts (Krummenauer et al. 2014). It is also robust, easy to operate, and economically feasible (Crab et al. 2012). The zero water exchange system has advantages of maintaining temperature and heat fluctuations (Crab et al. 2009). It supports nitrogen removal even when organic matter and biochemical oxygen demand of the system is high (Avnimelech 2015). It will be important for the future BFT to understand the microbial mechanisms involved in the process of flocculation viz., quorum sensing and controlling effect on pathogenic microbes. BFT also improves sustainability and biosecurity and development of high-intensity grow out systems with no water discharge over the entire crop cycle. It can also serve as a cheap and effective immunostimulant for the cultured organisms, so more research should focus on the optimal way to manage the BFT in the culture ponds.

\section{Conclusion}

The scarcity of water, growing demand for protein food, and conflict for land usage for the expansion of aquacultural practices have become a major problem at the global level. To cater to the growing demand for animal protein, intensive aquaculture is one of the major options. But intensification of aquaculture practices will generate a lot of effluents which will damage the aquatic environment. Moreover, the intensification will lead to heavy dependence on fish meal which is a scarce commodity, disease outbreaks in the cultured organisms, environmental degradation, and socioeconomic conflicts. In an attempt to minimize the impact of the environmental, health, and economic problems associated with aquaculture, BFT has become increasingly popular as a sustainable alternative for intensification (Avnimelech 1999, 2006; Browdy et al. 2001; Crab et al. 2007; De Schryver et al. 2008). The requirements for sustainable and eco-friendly aquaculture development can be fulfilled by the use of biofloc technology. 
Open Access This article is distributed under the terms of the Creative Commons Attribution 4.0 International License (http://creativecommons.org/licenses/by/4.0/), which permits unrestricted use, distribution, and reproduction in any medium, provided you give appropriate credit to the original author(s) and the source, provide a link to the Creative Commons license, and indicate if changes were made.

\section{References}

Ahmad I, Verma AK, Babitha Rani AM, Rathore G, Saharan N, Gora AH (2016) Growth, non-specific immunity and disease resistance of Labeo rohita against Aeromonas hydrophila in biofloc systems using different carbon sources. Aquaculture 457:61-67

Akiyama D, Doming WG, Lawrence AL (1992) Penaeid shrimp nutrition. In: Fast AW, Lester LJ (eds) Marine shrimp culture: principles and practices. Elsevier, Amsterdam, pp 535-568

Alexander JB, Ingram GA (1992) Noncellular nonspecific defence mechanisms of fish. Ann Rev Fish Dis 2:249-279

Anand PS, Kohli MPS, Kumar S, Sundaray JK, Roy SD, Venkateshwarlu G, Sinha A, Pailan GH (2014) Effect of dietary supplementation of biofloc on growth performance and digestive enzyme activities in Penaeus monodon. Aquaculture 418:108-115

Antonio M, Lorenzo D, Schveitzer R, Manoel C, Legarda EC, Quadros W, Vieira N (2015) Intensive hatchery performance of the Pacific white shrimp in biofloc system. Aquacultural Engineering 67:53-58

Asaduzzaman M, Wahab MA, Verdegem MCJ, Benerjee S, Akter T, Hasan MM, Azim ME (2009) Effects of addition of tilapia Oreochromis niloticus and substrates for periphyton developments on pond ecology and production in $\mathrm{C} / \mathrm{N}$-controlled freshwater prawn Macrobrachium rosenbergii farming systems. Aquaculture 287(3):371-380

Avnimelech Y, Weber B (1986) Studies in circulated fish ponds: organic matter recycling and nitrogen transformation. Aquaculture Fisheries Management 17:231-242

Avnimelech Y, Mokady S, Schroeder G (1989) Circulated ponds as efficient bioreactors for single cell protein production. Isr J Aquac Bamidgeh 41:58-66

Avnimelech Y, Kochva M, Diab S (1994) Development of controlled intensive aquaculture systems with a limited water exchange and adjusted carbon to nitrogen ratio. Isr J Aquac Bamidgeh 46:119-131

Avnimelech Y (1999) Carbon/nitrogen ratio as a control element in aquaculture systems. Aquaculture 176:227-235

Avnimelech Y (2006) Bio-filters: the need for an new comprehensive approach. Aquac Eng 34:172-178

Avnimelech Y (2007) Feeding with microbial flocs by tilapia in minimal discharge bio-flocs technology ponds. Aquaculture 264:140-147

Avnimelech Y, Kochba M (2009) Evalution of nitrogen uptake and excretion by tilapia in biofloc tanks, using ${ }^{15} \mathrm{~N}$ tracing. Aquaculture 287:163-168

Avnimelech Y (2015) Biofloc Technology, a Practical Guidebook, 3d Edition, pp 258, World Aquaculture Soc

Azim ME, Little DC (2008) The biofloc technology (BFT) in indoor tanks: water quality, biofloc composition, and growth and welfare of Nile tilapia, Oreochromis niloticus. Aquaculture 283:29-35

Bairagi A, Ghosh KS, Sen SK, Ray AK (2002) Enzyme producing bacterial flora isolated from fish digestive tracts. Aquac Int 10:109-121

Ballester ELC, Abreu PC, Cavalli RO, Emerenciano M, de Abreu L, Wasielesky JW (2010) Effects of practical diets with different protein levels on the performance of Farfantepeneau spaulensis juveniles nursed in zero exchange suspended microbial flocs intensive system. Aquac Nutr 16:163-172

Jesús Becerra-Dorame M, Martinez-Cordova LR, Martínez-Porchas M, Hernández-López J, López- Elías JA, Mendoza-Cano F (2014) Effect of using autotrophic and heterotrophic microbial-based-systems for the pregrown of Litopenaeus vannamei, on the production performance and selected haemolymph parameters. Aquaculture Research 45(5): 944-948

Bossier P, Verstraete W (1996) Triggers for microbial aggregation in activated sludge? Appl Microbiol Biotechnol 45(1-2):1-6

Browdy C, Bratvold D (2001) Perspectives on the application of closed shrimp culture systems In: Jory, E.D., Browdy, C.L. (Ed.), the new Wave, Proceedings of the Special Session on Sustainable Shrimp Culture, The World Aquaculture Society, Baton Rouge, LA, USA, pp. 20-34

Browdy CL, Bratvold D, Stokes AD, McIntosh RP (2001) Perspectives on the application of closed shrimp culture systems. In: The Rising Tide, Proceedings of the Special Session on Sustainable Shrimp Farming, The World Aquaculture Society, Baton Rouge, LA, USA, pp. 20-34

Brown MR, Jeffrey SW, Volkam JK, Dunstan GA (1997) Nutritional properties of microalgae for mariculture. Aquacult 151:315-331 
Burford MA, Thompson PJ, McIntosh RP, Bauman RH, Pearson DC (2004) The contribution of flocculated material to shrimp, Litopenaeus vannamei nutrition in a high-intensity, zero-exchange system. Aquacult 232: $525-537$

Corbel M (1975) The immune response in fish: a review. J Fish Biol 4:539-563

Crab R, Lambert A, Defoirdt T (2010) The application of bioflocs technology to protect brine shrimp, Artemia franciscana from pathogenic Vibrio harveyi. J Appl Microbiol 5:1643-1649

Crab R (2010a) Bioflocs technology: an integrated system for the removal of nutrients and simultaneous production of feed in aquaculture. $\mathrm{PhD}$ thesis, Ghent University. pp. 178

Crab R, Avnimelech Y, Defoirdt T, Bossier P, Verstraete W (2007) Nitrogen removal techniques in aquaculture for a sustainable production. Aquaculture 270:1-14

Crab R, Chielens B, Wille M, Bossier P, Verstraete W (2009) The effect of different carbon sources on the nutritional value of bioflocs, a feed for Macrobrachium rosenbergii postlarvae. Aquac Res 41:559-567

Crab R, Defoirdt T, Bossier P, Verstraete W (2012) Biofloc technology in aquaculture: beneficial effects and future challenges. Aquaculture 356-357:351-356

da Silva KR, Wasielesky W, Abreu PC (2013) Nitrogen and phosphorus dynamics in the biofloc production of the Pacific white shrimp. Litopenaeus vannamei. J. World Aquac. Soc. 44:30-41

De Schryver P, Crab R, Defoirdt T, Boon N, Verstraete W (2008) The basics of bio-flocs technology: the added value for aquaculture. Aquaculture 277:125-137

de Souza DM, Suita SM, Romano LA, Wasielesky W, Ballester ELC (2014) Use of molasses as a carbon source during the nursery rearing of Farfantepenaeus brasiliensis (Latreille, 1817) in a Biofloc technology system. Aquac. Res. 45:270-277

Ebeling JM, Timmons MB, Bisogni JJJ (2006) Engineering analysis of the stoichiometry of photoautotrophic, autotrophic, and heterotrophic removal of ammonia-nitrogen in aquaculture systems. Aquaculture 257:346-358

Emerenciano M, Ballester ELC, Cavalli RO, Wasielesky W (2011) Effect ofbiofloc technology (BFT) on the early postlarval stage of pink shrimp Farfantepenaeus paulensis: growth performance, floc composition and salinity stress tolerance. Aquac Int 19:891-901

Emerenciano M, Ballester ELC, Cavall RO, Wasielesky W (2012a) Biofloc technology application as a food source in a limited water exchange nursery system for pink shrimp Farfantepenaeus brasiliensis (Latreille, 1817). Aquac Res 43:447-457

Emerenciano M, Cuzon G, Goguenheim J, Gaxiola G (2012b) Floc contribution on spawning performance of blue shrimp Litopenaeus stylirostris. Aquac Res 44(1):75-85

Emerenciano M, Cuzon G, Paredes A, Gaxiola G (2013a) Evaluation of biofloc technology in pink shrimp Farfantepenaeus duorarum culture: growth performance, water quality, microorganisms profile and proximate analysis of biofloc. Aquac Int 21:1381-1394

Emerenciano M, Gaxiola G, Cuzon G (2013b) Biofloc technology (BFT): a review for aquaculture application and animal food industry. Biomass now: cultivation and utilization. InTech Rijeka Croatia 301-328

Emerenciano M, Cuzon G, Arevalo M, Gaxiola G (2014) Biofloc technology in intensive broodstock farming of the pink shrimp Farfantepenaeus duorarum: spawning performance, biochemical composition and fatty acid profile of eggs. Aquac Res 45(10):1713-1726

Fuller R (1989) Probiotic in man and animals. J Appl Bacteriol 66:365-378

Gaona CAP, Poersch LH, Krummenauer D, Foes GK, Wasielesky W (2011) The effect of solids removal on water quality, growth and survival of Litopenaeus vannamei in a biofloc technology culture system. International Journal of Recirculating Aquacult 12:54-57

Gutierrez-Wing MT, Malone RF (2006) Biological filters in aquaculture: trends and research directions for freshwater and marine applications. Aquac Eng 34:163-171

Hargreaves JA (2013) Biofloc Production Systems for Aquaculture. SRAC 4503:1-12

Hargreaves JA (2006) Photosynthetic suspended-growth systems in aquaculture. Aquac Eng 34:344-363

Hari B, Kurup BM, Varghese JT, Schrama JW, Verdegem MCJ (2006) The effect of carbohydrate addition on water quality and the nitrogen budget in extensive shrimp culture systems. AJSS 252:248-263

Jang IK, Pang Z, Yu J, Kim SK, Seo HC, Cho YR (2011) Selectively enhanced expression of prophenoloxidase activating enzyme 1 (PPAE1) at a bacteria clearance site in the white shrimp, Litopenaeus vannamei. BMC Immuno 12:70-80

Jendrossek D, Handrick R (2002) Microbial degradation of polyhydroxyalkanoates. Annu Rev Microbiol 56:403-432

Johnson CN, Barnes S, Ogle J, Grimes DJ, Chang YJ, Peacock AD, Kline L (2008) Microbial community analysis of water, foregut, and hindgut during growth of Pacific white shrimp, Litopenaeus vannamei, in closed-system aquaculture. J World Aquacult Soc 39:251-258 
Ju ZY, Forster I, Conquest L, Dominy W (2008) Enhanced growth effects on shrimp, Litopenaeus vannamei from inclusion of whole shrimp floc or floc fractions to a formulated diet. Aquac Nutr 14:533-543

Krummenauer D, Peixoto S, Cavalli RO, Poersch LH, Wasielesky W (2011) Superintensive culture of white shrimp, Litopenaeus vannamei, in a biofloc technology system in southern Brazil at different stocking densities. J World Aquacult Soc 42(5):726-733

Krummenauer D, Poersch L, Romano LA, Lara GR, Encarnacao P, Wasielesky JW (2014) The effect of probiotics in a Litopenaeus vannamei biofloc culture system infected with Vibrio parahaemolyticus. J Appl Aquac 26(4):370-379

Kuhn DD, Boardman GD, Lawrence AL, Marsh L, Flick GJ (2009) Microbial floc meal as a replacement ingredient for fish meal and soybean protein in shrimp feed. Aquacult 296:51-57

Kumar S, Anand PSS, De D, Sundaray JK, Raja RA, Biswas G, Ponniah AG, Ghoshal TK, Deo AD, Panigrahi A, Muralidhar M (2014) Effects ofcarbohydrate supplementation on water quality, microbial dynamics andgrowth performance of giant tiger prawn (Penaeus monodon). Aquac Int 22:901-912

Lancelot C, Billen G (1985) Carbon-nitrogen relationships in nutrient metabolism of coastal marine ecosystems. Advances in Aquatic Microbiology 3:263-321

Linan-Cabello M, Paniagua-Michel J, Hopkins P (2002) Bioactive roles of carotenoids and retinoids in crustaceans. Aquac Nutr 8:299-309

Mahanand SS, Moulick S, Rao PS (2013) Water quality and growth of Rohu, Labeo rohita, in a biofloc system. J Appl Aquac 25(2):121-131

McAbee BJ, Browdy CL, Rhodes RJ, Stokes AD (2003) The use of greenhouse-enclosedrace-way systems for the super intensive production of pacific white shrimp Litopenaeus vannamei in the United States. Global Aquaculture Advocate 6:40-43

Michaud L, Blancheton JP, Bruni V, Piedrahita R (2006) Effect of particulate organic carbon on heterotrophic bacterial populations and nitrification efficiency in biological filters. Aquac Eng 34:224-233

Milstein A, Avnimelech Y, Zoran M, Joseph D (2001) Growth performance of hybrid bass and hybrid tilapia in conventional and active suspension intensive ponds. Isr J Aquac Bamidgeh 53:147-157

Najdegerami EH, Bakhshi F, Lakani FB (2016) Effects of biofloc on growth performance, digestive enzyme activities and liver histology of common carp (Cyprinus carpio L.) fingerlings in zero-water exchange system. Fish Physiol Biochem 42:457-465

Naylor RL, Goldburg RJ, Primavera JH, Kautsky N, Beveridge MC, Clay J, Folke C, Lubchenco J, Mooney H, Troell M (2000) Effect of aquaculture on world fish supplies. Nature 405:1017-1024

Ninawe AS, Selvin J (2009) Probiotics in shrimp aquaculture: avenues and challenges. Crit Rev Microbiol 35 : 43-66

Otoshi CA, Tang LR, Moss DR, Arce SM, Holl CM, Moss S (2009) Performance of Pacific white shrimp, Penaeus (litopenaeus) vannamei, cultured in biosecure, super-intensive, recirculating aquaculture systems. BROWDY, CL; JORY, DE The rising tide-proceedings of the special session on sustainable shrimp farming. Baton Rouge: World Aquaculture Society

Perez-Fuentes JA, Perez-Rostro CI, Hernandez-Vergara MP (2013) Pond-reared Malaysian prawn Macrobrachium rosenbergii with the biofloc system. Aquaculture 400:105-110

Piedrahita RH (2003) Reducing the potential environmental impact of tank aquaculture effluents through intensification and recirculation. Aquaculture 226:35-44

Rahmatullah SM, Beveridge MCM (1993) Ingestion of bacteria in suspension Indian major carps (Catla catla, Labeo rohita) and Chinese carps (Hypophthalmichthys molitrix, Aristichthys nobilis). Hydrobiologia 264: 279-284

Ray AJ, Dillon KS, Lotz JM (2011) Water quality dynamics and shrimp (Litopenaeus vannamei) production in intensive, mesohaline culture systems with two levels of biofloc management. Aquac. Eng. 45:127-136

Rittmann B, McCarty P (2001) Environmental biotechnology: principles and applications. McGraw-Hill, New York, p 229

Salehizadeh H, Van Loosdrecht MCM (2004) Production of polyhydroxyalkanoates by mixed culture: recent trends and biotechnological importance. Biotechnol Adv 22:261-279

Samocha TM, Guajardo H, Lawrence AL, Castille FL, Speed M, McKee DA, Page KI (1998) A simple stress test for Penaeus vannamei postlarvae. AJSS 165:233-242

Samocha TM, Patnaik S, Speed M, Ali AM, Burger JM, Almeida RV, Ayub Z, Harisanto M, Horowitz A, Brock DL (2007) Use of molasses as carbon source in limited discharge nursery and grow-out systems for Litopenaeus vannamei. Aquac. Eng. 36:184-191

Saurabh S, Sahoo PK (2008) Lysozyme: an important defence molecule of fish innate immune system. Aquac Res 39:223-239

Schneider O, Sereti V, Eding E, Verreth J (2006) Molasses as C source for heterotrophic bacteria production on solid fish waste. AJSS 261:1239-1248 
Schveitzer R, Arantes R, Costodio PFS, Santo CMD, Arana LV, Seiffert WQ, Andreatta ER (2013) Effect of different biofloc levels on microbial activity, water quality and performance of Litopenaeus vannamei in a tank systemoperated with no water exchange. Aquac Eng 56:59-70

Sears K, Alleman JE, Barnard JL, Oleszkiewicz JA (2006) Density and activity characterization of activated sludge flocs. J Environ Eng 132:1235-1242

Simoni SF, Schafer A, Harms H, Zehnder AJB (2001) Factors affecting mass transfer limited biodegradation in saturated porous media. J Contam Hydrol 50:99-120

Smith VJ, Brown JH, Hauton C (2003) Immunostimulation in crustaceans: does it really protect against infection. Fish Shellfish Immunol 15:71-90

Tacon A, Cody JJ, Conquest LD, Divakaran S, Forster IP, Decamp OE (2002) Effect of culture system on the nutrition and growth performance of pacific white shrimp, Litopeneaus vannamei (bonne) fed different diets. Aquac Nutr 8:121-137

Tort L, Balasch JC, Mackenzie S (2003) Fish immune system. A crossroads between innate and adaptive responses. Immunologia 22:277-286

Trainer MA, Charles TC (2006) The role of PHB metabolism in the symbiosis of rhizobia with legumes. Appl Microbiol Biotechnol 71:377-386

Twarowska JG, Westerman PW, Losordo TM (1997) Water treatment and waste characterization evaluation of an intensive recirculating fish production system. Aquac Eng 16:133-147

Van der Marel M, Caspari N, Neuhaus H, Meyer W, Enss ML, Steinhagen D (2010) Changes in skin mucus of common carp Cyprinus carpio after exposure to water with a high bacterial load. J Fish Dis 33:431-439

Van Der Sar AM, Appelmelk BJ, Vandenbroucke-Grauls CMJE, Bitter W (2004) A star with stripes: zebrafish as an infection model. Trends Microbiol 12:451-457

Vazquez L, Alpuche J, Maldonado G, Agundis C, Pereyra-Morales A, Zenteno E (2009) Review: immunity mechanisms in crustaceans. Innate Immunity 15:179-188

Wang JK (2003) Conceptual design of a microalgae-based recirculating oyster and shrimp system. Aquac Eng 28:37-46

Wang YC, Chang PS, Chen HY (2008) Differential time-series expression of immune-related genes of Pacific white shrimp Litopenaeus vannamei in response to dietary inclusion of $\beta$-1, 3-glucan. Fish \& Shellfish Immunology 24(1):113-121

Wasielesky W, Atwood H, Stokes A, Browdy CL (2006) Effect of natural production in a zero exchange suspended microbial floc based super-intensive culture system for white shrimp, Litopenaeus vannamei. Aquaculture 258:396-403

Wilen BM, Jin B, Lant P (2003) The influence of key chemical constituents in activated sludge on surface and flocculating properties. Water Res 37:2127-2139

$\mathrm{Xu}$ WJ, Morris TC, Samocha TM (2016) Effects of C/N ratio on biofloc development, water quality, and performance of Litopenaeus vannamei juveniles in a biofloc-based, high-density, zero-exchange, outdoor tank system. Aquaculture 453:169-175

Xu WJ, Pan LQ (2012) Effects of bioflocs on growth performance, digestive enzyme activity and body composition of juvenile Litopenaeus vannamei in zero-water exchange tanks manipulating $\mathrm{C} / \mathrm{N}$ ratio in feed. Aquaculture 356-357:147-152

Xu WJ, Pan LQ (2013) Enhancement of immune response and antioxidant status of Litopenaeus vannamei juvenile in biofloc-based culture tanks manipulating high $\mathrm{C} / \mathrm{N}$ ratio of feed input. Aquaculture 412:117-124

Yoder JA, Nielsen ME, Amemiya CT, Litman GW (2002) Zebrafish as an immunological model system. Microbes and Infect 4:1469-1478

Zhao P, Huang J, Wang XH, Song XL, Yang C, Zhang XG, Wang GC (2012) The application of bioflocs technology in high-intensive, zero exchange farming systems of Marsupenaeus japonicus. Aquaculture 354355:97-106 